\title{
Processo judicial e poder político: práticas inquisitoriais no julgamento de condenação de Joana D'Arc
}

DOI: $10.15175 / 1984-2503-202113202$

\author{
Caio Cardoso Tolentino* \\ Paulo Eduardo Alves Silva**
}

\begin{abstract}
Resumo
Os registros do processo de condenação por heresia da guerreira francesa Joana D'Arc, de 1431 foram objeto de estudo em diferentes áreas. O presente trabalho explora as fontes primárias e alguns desses estudos com intuito de analisar o significado político das formas adotadas naquele julgado. Sob um olhar entre a história do direito e o direito processual, esclarece aspectos do funcionamento prático do processo inquisitorial romano-canônico ao fim da Idade Média e, mais amplamente, do fenômeno de capilarização do poder político através das formas de produção da verdade. O artigo conclui que o processo de Joana D'Arc, embora claramente político em suas intenções, corresponde em diversas dimensões às práticas processuais da época, levando-se ao entendimento de que a influência do poder sobre os julgamentos não se dá necessariamente pela violação direta das regras processuais, mas pela sua própria concepção e os modos em que são operacionalizadas.
\end{abstract}

Palavras-chave: Direito e política; formalismo processual; processo inquisitorial; Joana D’Arc.

Proceso judicial y poder político: prácticas inquisitoriales en el proceso de condena de Juana de Arco

\section{Resumen}

Las actas del proceso de condena por herejía de la guerrera francesa Juana de Arco en 1431 fueron objeto de estudio en diferentes ámbitos. El presente trabajo explora las fuentes primarias y algunos de estos estudios con el objetivo de analizar el significado político de las formas procedimentales adoptadas en ese juicio. Desde una perspectiva a medio camino entre la historia del derecho y el derecho procesal, aclara aspectos del funcionamiento práctico del proceso inquisitorial romano-canónico a finales de la Edad Media y, de forma más extensa, del fenómeno de capilarización del poder político a través de las formas de producción de la verdad. El artículo concluye que el proceso de Juana de Arco, pese a ser claramente político en sus intenciones, corresponde en varias dimensiones a las prácticas procesales de la época, lo que lleva a entender que la influencia del poder en los juicios no se produce necesariamente a través de la violación directa de las normas procesales, sino a través de su propia concepción y de la forma en que se ponen en práctica.

Palabras clave: derecho y política; forma procedimental; proceso inquisitorial; Juana de Arco.

\footnotetext{
* Graduando da Faculdade de Direito Ribeirão Preto da Universidade de São Paulo (FDRP/USP). Pesquisador pelo Programa de Iniciação Científica sem Bolsa da FDRP/USP. E-mail: caiotolentino@usp.br.

(6) http://lattes.cnpq.br/7638110751639339. (1) https://orcid.org/0000-0003-1853-4994

** Professor da Faculdade de Direito de Ribeirão Preto da Universidade de São Paulo (FDRP/USP). Mestre, Doutor e Livre-Docente pela Universidade de São Paulo. E-mail: pauloeduardoalves@usp.br.

(2) http://lattes.cnpq.br/8525107983606820. (1) https://orcid.org/0000-0002-4069-9405
} 
Legal proceedings and political power: Inquisitorial practices in the trial and sentencing of Joan of Arc

\begin{abstract}
Records on the trial and sentencing for heresy of French warrior Joan of Arc dating to 1431 have been studied by a variety of fields. The present work explores the primary sources and several of these studies in the aim of analyzing the political significance of the forms adopted during the trial. From a perspective poised between the history of law and procedural law, the article clarifies aspects of the practical functioning of the Roman Canon inquisitorial procedure at the end of the Middle Ages, and, more widely, the phenomenon of the capillarization of the political power by means of the production of truth. The article concludes that, although Joan of Arc's trial was clearly politically motivated, several of its dimensions correspond to the procedural practices of the time, leading us to an understanding that the influence of power over trials does not necessarily manifest in a direct violation of procedural rules, but rather in their very design and the ways in which they are put into operation.
\end{abstract}

Keywords: Law and politics; procedural formalism; inquisitorial procedure; Joan of Arc.

\title{
Procès judiciaire et pouvoir politique : Pratiques inquisitoriales de la condamnation de Jeanne d'Arc
}

\section{Résumé}

Les archives du procès en hérésie de la combattante française Jeanne d'Arc, tenu en 1431, ont fait l'objet de travaux dans différentes disciplines. Nous avons, aux fins du présent article, exploité les sources primaires et certains des travaux en question dans le but d'analyser la signification politique des formes adoptées lors de ce jugement. Sous une perspective à la croisée de l'histoire juridique et du droit processuel, il s'agira de mettre en lumière certains aspects du fonctionnement pratique du procès inquisitorial romano-canonique à la fin de la période médiévale, et, plus largement, du phénomène de capillarisation du pouvoir politique par le biais des formes de production de la vérité. Nous en avons conclu que le procès de Jeanne d'Arc, encore que clairement politique dans ses intentions, correspond sous bien des aspects aux pratiques processuelles de l'époque, ce qui nous amène à penser que l'influence du pouvoir sur les jugements ne passe pas nécessairement par la violation directe des règles de procédures, mais par leur propre conception et leurs modes de mise en œuvre.

Mots-clés : Droit et politique ; formalisme processuel ; procès inquisitorial ; Jeanne d'Arc.

\section{司法程序和政治权力：十五世纪法国对圣女贞德的审讯实践}

\section{摘要:}

法国中世纪后期的女英雄乔安娜·达尔克（Joana D'Arc）的故事流传甚广，她在死后被封为圣女贞德。来自不 同的领域的学者们研究了1431年法国对圣女贞德的异端罪的审讯与定罪过程的记录，获得了很多成果。本文 利用第一手资料和已有的一些研究成果，分析了审判程序所代表的政治含义。我们从法律史和程序法的角度阐 述了中世纪末期按照罗马法审判案件的具体实践，我们认为，该司法实践中，通过审讯所产生的“真相” 反映 了当时法国的政治权力的格局，审讯本身对均衡当时的政治权力有很大的意义。我们的结论是，虽然圣女贞德 案的审判过程具有明显的政治意图，但是它符合当时的司法程序和司法实践。这就是说，政治对司法的影响不 一定是通过打破正常的司法程序和规定而实现，程序和它的实际操作，本身就是政治的一部分。

关键词：法律与政治；程序形式主义；审讯过程；乔安娜·达尔克 (Joana D'arc). 


\section{Introdução}

As formas dos julgamentos, enquadradas nas ciências jurídicas no ramo do direito processual, possuem, além dos aspectos técnico-formais, uma dimensão sociopolítica comumente desconsiderada nos estudos da área, ocupados prioritariamente da produção dogmática.

A história, diferentemente, é repleta de julgamentos que confirmam e ilustram a importância política das regras processuais. O processo de condenação da guerreira francesa Joana D'Arc é um deles. Considerado um dos registros mais detalhados de um julgamento da Idade Média europeia (HOBBINS, 2005), é um material rico para o estudo da consolidação das práticas inquisitoriais e das atividades de produção da verdade pelos processos judiciais.

Joana D’Arc, personagem histórica da Guerra dos Cem Anos, foi capturada em batalha por franceses aliados à Inglaterra em 1430 e, entre janeiro e maio de 1431, julgada e condenada por heresia por suas famosas visões religiosas. Conduziram o julgamento o bispo francês Pierre Cauchon e o vice-inquisidor da França, Jean le Maistre, entre outras autoridades - inclusive um conselho de juristas e teólogos da Universidade de Paris, como era comum à época. Alguns anos após sua execução, um novo julgamento, chamado de julgamento de reabilitação ou de nulificação, dessa vez em contexto político diverso, culminou na anulação da condenação (HOBBINS, 2005).

Extensamente documentado, o registro desses processos fornece precioso material de análise da operação prática das instituições processuais canônicas medievais. O campo da história produziu diversos e valiosos estudos sobre a vida de Joana e o contexto político da guerra. No do direito, há produções igualmente relevantes, mas ainda há o que explorar sobre o papel das figuras jurídicas e processuais utilizadas naquele julgamento (HOBBINS, 2005). No direito processual particularmente, a fonte documental pode ajudar na compreensão de como se consolidou o modelo moderno de julgamentos e orientar, no campo dogmático, a compreensão dos elementos que integram a cláusula do devido processo legal à época, reduzindo os anacronismos comuns nesse tipo de análise.

A pesquisa que fundamentou esse texto analisou a aplicação prática de algumas figuras processuais relevantes no desenrolar do julgamento de Joana D'Arc, desde suas fases preliminares até as sentenças. A despeito da diversidade de mecanismos e procedimentos adotada pelos inquisidores e das diferenças em função do tempo e da 
região, as informações levantadas ajudam a elucidar aspectos do funcionamento do processo inquisitorial na Baixa Idade Média.

A principal fonte histórica utilizada são os próprios autos do processo de condenação de Joana D'Arc, registrados em 1431 em latim e francês e ora analisados por versão em língua inglesa. ${ }^{1}$ A pesquisa bibliográfica foi usada para a compreensão do processo inquisitorial em seus diversos níveis, pelo estudo dos institutos processuais através das fontes formais de direito romano-canônico, do pensamento de juristas da época, do tratamento nos manuais práticos de inquisidores e de aspectos do funcionamento dos tribunais.

A análise recorre à interpretação sobre a história dos julgamentos feita por Foucault, como consolidação do mecanismo de investigação racional da verdade e seus usos no âmbito das relações de poder (FOUCAULT, 2011). A hipótese é de que a penetração do poder no processo judicial depende menos de práticas explícitas de violação de regras formais e se esconde nos momentos da concepção e de uso (e desuso) em situações específicas, conforme a conveniências ditadas pela política. A ilustração mais evidente da hipótese é a própria escolha por submeter Joana a um processo inquisitorial pelo crime de heresia, com estratégias específicas para a consolidação da verdade relevante à disputa política da época.

\section{A natureza política do processo judicial e o caso de Joana D’Arc}

Importante, de início, recuperar algumas noções relativamente consolidadas na literatura em história do direito sobre as características peculiares do ordenamento jurídico medieval e pré-moderno, as quais servem para guiar a análise do documento e as discussões aqui apresentadas.

Aquele extenso período costuma ser caracterizado pelo pluralismo que marcava o ambiente sociojurídico - segundo Hespanha (2012, p. 161), "[um]a situação em que distintos complexos de normas, com legitimidades e conteúdos distintos, coexistem no mesmo espaço social". Convivem e entrelaçam-se, em um mesmo espaço e tempo, ordenamentos do chamado direito comum, formado principalmente pelos direitos romano e

\footnotetext{
${ }^{1}$ Será aqui utilizada a tradução inglesa do texto em latim realizada por Hobbins (2005). Como explica Hobbins (2005), o texto francês consiste basicamente na minuta das audiências, escrita e organizada diariamente pelos notários. Estão ausentes, contudo, diversos documentos presentes na versão oficial em latim, como cartas, pareceres e mandados. Certo debate histórico foi travado quanto à confiabilidade do texto traduzido, advogando Hobbins (2005) pela relativa fidelidade da tradução; de qualquer modo, divergências relevantes entre as versões serão pontuadas ao longo do trabalho, para melhor esclarecimento de algumas passagens.
} 
canônico, mas também pelo direito comercial, e direitos particulares de localidades específicas. Nenhum deles com hegemonia absoluta sobre as demais (HESPANHA, 2012).

O papel dos juristas e dos regramentos normativos formais naquele contexto também é diverso do que concebemos atualmente. O direito não era criado ou retificado pelo trabalho legislativo ou pela atividade teórico-doutrinária, mas antes descoberto e revelado através de princípios contidos na natureza (HESPANHA, 2012). Isso implica em um relativo e importante afastamento da noção moderna de legalidade. Leis e ordenamentos formais não possuem a mesma importância para as atividades de administração dos conflitos que têm hoje, prevalecendo nos julgamentos dose ainda maior de casuísmo (ARAÚJO; VALLE, 2019; GROSSI, 2004). ${ }^{2}$ O crédito era dado aos textos não por sua autoridade, mas por sua contribuição à justiça (GROSSI, 2004).

Tais características influenciam e marcam o processo inquisitorial. Hobbins (2005), ao tentar analisar a conformidade do processo de Joana D'Arc ao que seria esperado de um processo judicial da época, destaca o desafio preliminar de se definir o processo inquisitorial romano-canônico ideal, se é que existia algum. Isso porque as diversas fontes do direito que o instruíam - dentre as quais as determinações escritas da cúria papal, ${ }^{3}$ seus comentários e glosas, os tratados processuais universitários, os manuais inquisitoriais ${ }^{4}$ e o próprio costume - adquiriam diferentes e variáveis níveis de autoridade, difíceis de serem identificados em determinado lugar e tempo.

A compreensão das formas processuais e de julgamento da época escapam, portanto, das análises meramente dogmáticas, restritas à comparação entre institutos e mecanismos específicos. É necessário ampliar o olhar para ao contexto sociopolítico vigente, bem como ao jogo travado entre os atores políticos envolvidos, para se compreender as regras processuais e as práticas judiciárias.

Nesse sentido mais amplo, as formas de julgamento possuem relevante papel na criação e legitimação das verdades que pautam toda organização social e na intermediação das relações entre o poder e a verdade (FOUCAULT, 2011). Na perspectiva foucaultiana,

\footnotetext{
${ }^{2}$ No direito canônico, de especial relevância para o presente trabalho, existia uma preocupação em se realizar a justiça no caso concreto para a salvação daquele indivíduo pecador específico, traduzida no princípio da aequitas canonica, o que reforça o ambiente de casuísmo mencionado (GROSSI, 1998).

${ }^{3}$ Frise-se que mesmo os cânones, bulas e decretos papais, os quais parecem, ao leitor moderno, dotados de abstração e generalidade tais quais as leis de um Estado Moderno, encontram-se imersos nesse ambiente de casuísmo, intimamente ligados a situações locais e casos concretos, como demonstra Rust (2014) ao tratar da Bula Ad Extirpanda de 1252, celebremente citada por autorizar o uso da tortura judicial.

4 Estes eram escritos pelos próprios inquisidores, de modo que geralmente tratavam de questões mais práticas e eram avessos a explicações teóricas. Entre os mais famosos, podemos citar os de Bernard Gui, escrito no início do século XIV, e o de Nicholas Eymerich, escrito ao final do mesmo século (HILL, 2019).
} 
a verdade não seria um conceito existente a priori, a ser descoberto pelo sujeito de conhecimento, mas o resultado de uma construção social que é contingente diante de determinados tipos de domínios de saber e tipos de sujeitos de conhecimento, formados a partir de relações políticas na sociedade. ${ }^{5}$

O estudo crítico dos julgamentos e formas processuais, nesse sentido, pode servir para a compreensão de como se dão os processos de produção da verdade, os meios pelos quais determinado discurso é considerado válido. Esses elementos podem ser buscados justamente nas formas e procedimentos jurídicos (FOUCAULT, 2011), emergentes de situações sociais, históricas e políticas externas ao campo do direito - o que, de algum modo, vai de encontro ao tratamento endogênico conferido pelos estudos com finalidade predominantemente dogmática e que não levam em conta a historicidade do sujeito de conhecimento (FONSECA, 2012).

A premissa de que os processos judiciais refletem, em diferentes níveis de importância, as relações de poder que lhe constituem o contexto não implica em concluir que a penetração da política no processo se dê pela violação de regras processuais ou por julgamentos explicitamente contra-legem - como comumente se faz ao afirmar que este ou aquele julgamento teria "cunho político". Antes, parece apresentar-se na própria concepção das formas jurídicas e na sua operacionalização em situações específicas para legitimar determinadas verdades. Em algum sentido, é o que também se deduz pela compreensão de Foucault do poder como prática e estratégia de produção da verdade independentemente de questionamentos de legalidade ou legitimidade (MORAIS, 2014), imiscuída em procedimentos formais e diluída em canais capilares.

Essa abordagem parece especialmente interessante para a análise do julgamento de Joana D'Arc. O caso possui evidente papel político dentro da Guerra dos Cem Anos, vez que dirigido contra uma aliada do Rei Charles da França. As "vozes" ouvidas por Joana, sobre as quais depôs e pelas quais foi condenada, eram políticas nesse sentido: diziam que era a vontade de Deus que os ingleses fossem expulsos da França e a ordenavam a se juntar à

\footnotetext{
5 "Cada sociedade tem seu regime de verdade, sua "política geral" de verdade: isto é, os tipos de discurso que ela acolhe e faz funcionar como verdadeiros; os mecanismos e as instâncias que permitem distinguir os enunciados verdadeiros dos falsos, a maneira como se sanciona uns e outros; as técnicas e os procedimentos que são valorizados para a obtenção da verdade; o estatuto daqueles que têm o encargo de dizer o que funciona como verdadeiro" (FOUCAULT, 2007, p. 12). O poder, na mesma linha, se manifestaria como "uma série de práticas e estratégias, ligadas a interesses políticos ocultos, cujo objetivo é dominar e produzir. O poder não se concentra em instituições ou centros, mas deve ser vislumbrado como uma rede, que a tudo e todos perpassa, estendendo-se para os saberes e, até mesmo, para o que se entende por verdade" (MORAIS, 2014, p. 288).
} 
batalha ao lado do Rei Charles, ${ }^{6}$ de onde a vontade de partidários dos ingleses de provar que Joana estaria enganada e não passaria de uma herege é verossímil (HOBBINS, 2005). O julgamento também envolve questões socialmente sensíveis à época - como o controle da sexualidade feminina, ${ }^{7}$ exemplificada pela acusação de uso das roupas masculinas, bem a relevância político-religiosa de evitar as dissidências da fé católica. ${ }^{8}$

O estudo das formas processuais daquele julgamento vai muito além dos mecanismos, técnicas e procedimentos adotados. Depende, em boa medida, da explicitação dos usos possíveis de um processo de validação de determinada verdade. Em nenhum sentido, portanto, consegue ser neutro e apolítico. $O$ direito não é neutro e o processo judicial, tampouco. A escolha do uso do processo inquisitorial por heresia, por exemplo, oficialmente coordenado pela Igreja Católica, mas não pelos inimigos de Joana, ajudou na construção de determinada narrativa sobre a figura da acusada que servia aos propósitos de alguns dos principais atores políticos da ocasião.

Paralelamente, a análise das formas de julgamento utilizadas no caso de Joana D’Arc também permite ilustrar a transição para um novo modelo de produção da verdade que Foucault identifica renascer na Baixa Idade Média: o inquérito, baseado na colheita do depoimento de testemunhas e no interrogatório do suspeito, em contraposição ao antigo modelo das provas de força (FOUCAULT, 2011). ${ }^{9} \mathrm{O}$ ressurgimento do inquérito, ocorrido inicialmente no âmbito dos processos eclesiásticos, relaciona-se à crescente concentração política na Baixa Idade Média, inclusive nas mãos da Igreja Católica, a qual, por seu turno, influenciava decisivamente no desenho e aplicação das suas regras (FOUCAULT, 2011;

\footnotetext{
${ }^{6}$ A natureza política das vozes de Joana é claramente perceptível no depoimento de 17 de março de 1431: "Asked whether she knows whether Saint Catherine and Saint Margaret hate the English, she answered: "They love what God loves and hate what God hates." Asked whether God hates the English, she said she knows nothing about the love or hate that God has for the English, nor what he will do with their souls; but she knows for certain they will be driven from France, except those who stay and die, and that God will grant the French victory over the English" (HOBBINS, 2005, p. 110-111). Tradução nossa: "Questionada se sabia se Santa Catarina ou Santa Margarida odeiam os ingleses, ela respondeu: 'Elas amam o que Deus ama e odeiam o que Deus odeia'. Questionada se Deus odeia os ingleses, ela disse que nada sabe sobre o amor ou ódio que Deus tem pelos ingleses, nem o que ele fará com suas almas; mas sabe por certo que eles serão expulsos da França, exceto aqueles que ficarem e morrerem, e que Deus garantirá aos franceses a vitória sobre os ingleses".

${ }^{7}$ Para um exemplo de estudo do julgamento sob o olhar da sexualidade, ver Crane (1996). Para uma revisão da bibliografia sobre a conexão entre crimes de heresia e feitiçaria e a sexualidade feminina, ver Araújo (2019).

${ }^{8}$ Outros elementos do caso reforçam seu caráter político. Pierre Cauchon, o bispo que coordenou o processo, desenvolveu sua carreira pela aproximação a figuras relevantes da Inglaterra e da Borgonha, lado oposto ao de Joana na disputa. Além disso, o julgamento só foi possível por causa de concessão do Rei Inglês, vez que a acusada era sua prisioneira, como mostram cartas trocadas entre o rei e Cauchon, inclusive no processo (HOBBINS, 2005). Documentos financeiros demonstram que a Inglaterra efetuou pagamentos a Cauchon (KELLY, 2014).

${ }^{9}$ Mais famosa das épreuves, os ordálios desapareceram a partir do IV Concílio de Latrão em 1215, momento em que foi proibida a participação dos clérigos nesse tipo de procedimento, implicando em seu efetivo desuso (LOPES, 2011a).
} 
FRAHER, 1989b, 1992). ${ }^{10}$ Como técnicas de produção da verdade adotadas pelo instrumento processual do inquérito, seu estudo contribui a uma melhor compreensão de como o poder se manifesta e se efetiva nos julgamentos pela via dos instrumentos e técnicas processuais.

\section{Características gerais do processo inquisitorial e das inquisições católicas na Baixa Idade-Média}

O processo inquisitorial foi introduzido no direito canônico na Baixa Idade Média, instituído a partir de cânone papal publicado no IV Concílio de Latrão, em 1215. Dentre suas características, destaca-se a atribuição ao juiz das iniciativas de investigação e de acusação penal (PENNINGTON, 2016). ${ }^{11}$ Adotado inicialmente para a administração interna da Igreja Católica, esse modelo é posteriormente absorvido pela jurisdição secular, definindo a matriz jurídica medieval. O modelo do processo inquisitorial não era exclusivo para a perseguição das heresias estabelecida pela Igreja Católica, mas um padrão para o processamento dos feitos criminais e cíveis em tribunais seculares e eclesiásticos do continente até o século XVIII. Sua herança histórica é marcante inclusive no processo continental atual (LOPES, 2011b). ${ }^{12}$

As origens desse modelo remontam, com certas diferenças, à forma procedimental da inquisitio, presente no modelo romano da cognitio extra ordinem e retomada séculos mais tarde nos estudos do Corpus luris Civilis pelos juristas medievais (PETERS, 1988). Como se sabe, esse reaproveitamento acontece pela adaptação das regras do direito romano a uma realidade social e política completamente distinta daquela do Corpus - um trabalho de criação e interpretação legislativa e doutrinária que não raro recorria aos textos

\footnotetext{
${ }^{10}$ Fraher $(1989 b, 1992)$ explica como a revolução processual do inquérito eclesiástico e a abolição dos ordálios, que culminou no IV Concílio de Latrão em 1215, se encontra conectada às necessidades administrativas de centralização e controle da Igreja Católica surgidas a partir das reformas gregorianas no século XI.

11 O referido cânone, intitulado "Qualiter et Quando", oficializou a presença de três formas processuais no direito romano-canônico: a accusatio, a inquisitio e a denunciatio. A inquisitio e a denunciatio se diferenciavam somente pela maneira de se iniciar o processo: a primeira de ofício pela fama do suspeito, a segunda via denúncia do crime. Na prática, a única forma a prevalecer na persecução criminal foi a inquisitio, visto que a accusatio trazia o risco de aplicação da lex talionis ao acusador na hipótese de absolvição (PENNINGTON, 2016). Sobre as revoluções processuais do IV Concílio de Latrão em 1215, as quais incluíram o desaparecimento dos ordálios, a formalização da inquisitio e a exigência de um processo escrito, todas interpretadas como maneiras de centralizar e facilitar o controle do processo canônico, ver Fraher (1992).

12 Tratando-se de sistemas jurídicos contemporâneos, a tradicional classificação comparada das formas de administração da justiça em inquisitórias ou acusatórias tem recebido críticas tais quais a de Damaška (1986), que defende a superação da dicotomia por uma análise bifocal relacionada à estrutura da autoridade estatal e às funções de governo, o que não impede seu uso em sentido histórico, como já o fez o próprio autor (DAMAŠKA, 2012).
} 
romanos como argumento de autoridade e legitimidade (GROSSI, 2006; INIESTA; CORETTI, 2019). ${ }^{13}$

O modelo moderno de investigação racional da verdade, segundo o interpreta Foucault (2011), surge na mesma época junto à crescente centralização no exercício do poder nas mãos do soberano e a concepção da natureza pública do crime, pela figura da infração. ${ }^{14}$ Sob a concepção anterior, equiparada a simples violação privada, a intervenção do soberano julgador era bem mais restrita. De modo correspondente, a heresia passou a ser considerada, no direito canônico, como crimen lesae maiestatis divinae - uma ofensa direta à unicidade da cristandade latina, que buscava se afirmar como uma sociedade juridicamente regulada e hierarquicamente dirigida (PETERS, 1988). ${ }^{15}$

No que se refere especificamente à persecução das heresias pela Igreja Católica, são, todavia, distintas as inquisições tardo-medievais e o modelo inquisitório de julgamento a que nos remete o senso comum, sobretudo no que diz respeito à centralização da autoridade julgadora e do respectivo modelo de produção da verdade pelo processo. As inquisições instauradas entre os séculos XIV e XVI são caracterizadas por respostas flutuantes e ad hoc às ameaças de heresia. As práticas legais e processuais romanocanônicas encontravam-se em consolidação, não se podendo falar em uma entidade burocrática e unificada chamada "Inquisição", mas em inquisidores com atuação isolada, representantes às vezes da autoridade papal, às vezes dos bispos locais (PETERS, 1988). Esse perfil é bem diverso do modelo idealizado pela figura de uma única "Inquisição" centralizada, com regras bem definidas e conectadas a um aparato estatal, tal como se observa posteriormente em Portugal, Espanha e Itália a partir do final do século XV. ${ }^{16}$

Além disso, esse período da história da Igreja não é marcado pelas persecuções necessariamente voltadas a eliminar grupos espirituais específicos, como havia ocorrido no

\footnotetext{
${ }^{13}$ Conforme explica Fraher (1989a) especificamente sobre o processo penal, os juristas escolásticos tinham o papel de mediar a tensão entre a estrutura intelectual do ius commune e a rápida evolução da percepção social de crime.

${ }^{14}$ Fraher (1984), por exemplo, analisa a repercussão da máxima rei publicae interest, ne crimina remaneant impunita ("sendo de interesse público, nenhum crime permanecerá impune"), a qual é replicada pelos juristas para justificar a adoção do processo inquisitório e, muitas vezes, para afastar determinadas regras processuais protetoras do acusado.

15 Prodi (2005) fala da transposição da noção de majestade do plano político para o plano espiritual.

16 Alguns estudos realizados no Brasil não esclarecem esse aspecto desorganizado e fragmentado das inquisições medievais, tratando o fenômeno inquisitorial de maneira presumivelmente organizada e planejada, tal qual o faz Naspolini (2006). Também não ressaltam o fato de que o processo inquisitorial, apesar de nascido na Igreja Católica, não é fenômeno exclusivo do direito canônico e foi utilizado na persecução de diversos crimes além do de heresia e feitiçaria, fazendo parte da moldura jurídica do ius commune.
} 
combate aos cátaros, por exemplo. Os inquisidores também direcionavam sua atenção a hereges desconectados de qualquer movimento organizado (PETERS, 1988).

Apesar do que sugere o senso comum, o processo inquisitorial não era um exercício livre de barbárie e discricionariedade, ao menos segundo a perspectiva da época. ${ }^{17}$ Formalmente, aquele modelo processual não era vazio de regras, as quais serviriam, em última análise, como limitação objetiva da ação do inquisidor.

Segundo dão notícia os manuais de inquisidores, como o de Nicholas Eymerich e Bernard Gui, as inquisições para perseguição dos hereges (inquisitio haereticae pravitatis) seguiam, resumidamente, o seguinte procedimento: estabelecida a inquisição em determinado lugar, instituía-se um período de um ano de "graça", durante o qual pessoas que espontaneamente confessassem práticas condenáveis seriam tratadas com penas reduzidas, tais quais o carregamento de cruzes (HILL, 2019). ${ }^{18} \mathrm{O}$ processo, propriamente, era instaurado pelo inquisidor através de denúncia (denunciatio) ou meramente através da verificação ou constatação da "fama" do suspeito que motivasse a persecução (inquisitio) (PENNINGTON, 2016). ${ }^{19}$ Em seguida, o juiz ouvia as testemunhas e interrogava o acusado - geralmente mantido sob custódia em prisão eclesiástica e, por vezes, com uso da tortura. Após o interrogatório, o inquisidor geralmente buscava extrair uma confissão (também chamada de abjuração, por conter elementos de arrependimento religioso) do acusado. Ao final, proferia-se a sentença absolutória ou condenatória, privativamente ou na cerimônia pública do auto de fé, atribuindo-se penas que poderiam variar entre condenação ao carregamento de cruzes, peregrinação, prisão perpétua ou por tempo determinado e a pena capital, celebremente chamada de "entrega ao braço secular" (HILL, 2019, p. 92-93).

A literatura romano-canônica da época revela certa preocupação com a observância de formas processuais pelo juiz, contrariamente ao que supõe o senso comum. Dentre elas, a presença de defensores, a leitura das acusações ao suspeito, a possibilidade de recursos,

\footnotetext{
17 A tradicional compreensão do fenômeno inquisitorial como perseguição desenfreada, frequentemente através de lentes de forte carga valorativa, é chamada de "lenda negra da Inquisição", a qual encontra eco não somente no pensamento popular, mas também na produção historiográfica e jurídica, sendo, contudo, rejeitada ou mitigada pelos mais recentes trabalhos acadêmicos (ARAÚJO; VALLE, 2019).

18 Hill (2019) afirma que o período de graça é naturalmente mecanismo das inquisições papais itinerantes, não sendo muito aplicável, portanto, a inquisições sedentárias tais quais as de Bernard Gui em Toulouse ou, no mesmo sentido, as episcopais (feitas pelo bispo em sua diocese), embora o valor da confissão espontânea seja reconhecido de qualquer modo para aliviar-se as penas.

19 Sobre os procedimentos da inquisitio, denunciatio e accusatio, este último largamente em desuso a partir do IV Concílio de Latrão em 1215, ver nota 11 supra. Entre os mecanismos de detecção de hereges, Hill (2019) descreve o uso do período de graça, as denúncias espontâneas, a concessão de imunidade ou redução da pena para que suspeitos ajudem na captura de seus companheiros, o auxílio das autoridades seculares e eclesiásticas e de próprios membros da população.
} 
a necessidade de investigações preliminares para o início da inquisição de ofício, entre outros (ULLMANN, 1988, p. 481-489, apud LOPES, 2011a, p. 94; KELLY, 1989).

Em verdade, o conceito de ordo judiciarius, entendido como um corpo de regras particulares a que hoje chamaríamos de direito processual, não era estranho aos juristas medievais, sendo possível observar a proliferação de diversas obras e manuais de processo que espelham essa preocupação (FRAHER, 1989a; PENNINGTON, 2016). ${ }^{20}$ Eichbauer (2014), sumarizando pesquisas realizadas nos últimos anos, demonstra como os séculos XII e XIII foram caracterizados, no âmbito do ius commune, por um crescente estabelecimento de regras processuais protetoras do acusado lastreadas no direito natural. DAMAŠKA (2012, p. 936) esclarece, todavia, que tais noções de "devido processo legal" não eram vistas como direitos subjetivos do acusado, mas sim como imposições objetivas ao juiz fundamentadas na lei divina; não eram, portanto, direitos no sentido moderno da palavra, menos ainda garantias e liberdades individuais, sequer concebidas à época. ${ }^{21}$

Ainda assim, as regras de natureza processual, conquanto tratadas nas fontes papais e nos escritos teóricos, não eram sempre observadas na prática judicial. Peculiaridades dos órgãos de julgamento e, também, do perfil e prestígio social dos acusados justificavam certa adaptação das regras - adotava, por exemplo, um rigor processual maior na investigação de pessoas socialmente mais importantes (DAMAŠKA, 2012). ${ }^{22}$ Eichbauer (2014) e Fraher (1989b) explicam também que, em casos de heresia e outros crimes de grave ofensa ao interesse público, como traição e feitiçaria, admitia-se maior flexibilidade processual e se adaptavam os procedimentos a fim de facilitar a persecução penal e a imposição das penas.

\footnotetext{
${ }^{20}$ Aqui, além dos já citados manuais inquisitoriais, direcionados especificamente a processos de heresia, podemos mencionar as obras de Tancredo de Bolonha, Thomas de Piperata, Guilherme Durando, Johannes Andreae, Baldo de Ubaldis e Alberto Gandinus (FRAHER, 1989a).

${ }^{21}$ Assim, regras de processo romano-canônico eram justificadas com passagens diretas da Bíblia. A necessidade de citação, por exemplo, era frequentemente argumentada com o chamado de Deus por Adão antes de expulsá-lo do Éden ("Adam, ubi es"?); o fundamento da função inquisitiva do juiz advinha da descida de Deus a Sodoma e Gomorra para investigar a verdade (PENNINGTON, 2016). Fraher (1989a, p. 29) afirma que o juiz estava circunscrito às "solenidades da lei". Como também avalia Prosperi (2013, p. 232, apud ARAÚJO; VALLE, 2019, p. 37) sobre a concepção reduzida de sujeito dos pré-modernos, "aqui não se tratava de direitos do indivíduo, mas dos deveres das autoridades para a salvação das almas".

${ }^{22}$ Aqui, Damaška cita como exemplo um julgamento do século XVI cujo acusado era um nobre importante no local. Nesse processo, a aplicação da tortura e a validade da confissão judicial foram vistas de maneiras diversas ao se investigar o nobre e ao se investigar outros acusados de qualificação social menos importante, ou ao se extrair depoimento de testemunha de igual posição social.
} 


\section{Estudo dos elementos processuais no processo de condenação de Joana D'Arc}

As peculiaridades do processo inquisitorial medieval, ora orientado por rigoroso formalismo processual, ora flexibilizado conforme as circunstâncias exigiam, são ilustrados pela análise de institutos registrados no processo de condenação de Joana D'Arc, apresentados nos itens que seguem.

Entre os autores que se dedicaram a uma análise jurídica do julgamento, destacamse as contribuições de Kelly (1993; 2014) e Hobbins (2005). Kelly, partindo de uma noção mais formalista do direito medieval, afirma que o processo de Joana é caracterizado por uma violação sistemática dos limites oficialmente impostos pela regulação papal ao juiz, enquanto Hobbins afirma que, dentro do possível, os juízes buscaram observar as regras processuais, de maneira a evitar dúvidas quanto à regularidade do julgamento. Peters (1988) ainda afirma que o processo apresenta algumas características comuns ao processo inquisitorial da época, porém aparenta divergir em outros aspectos, como o baixo nível probatório aceito pelos juízes e a manutenção de Joana em uma prisão inglesa, e não eclesiástica.

A análise que seguirá transita pelas questões trazidas por essa literatura, adotandose as premissas histórico-jurídicas estabelecidas e o olhar foucaultiano sobre as relações entre poder, verdade e processo.

\section{A comprovação da publica fama como requisito para o início do processo}

Como explica Migliorino (2016) as noções de "fama" e infamia ocupam importante espaço dentro da sociedade medieval, de modo que a estima social de um indivíduo ou, ao contrário, uma conduta ou modo de vida repreensíveis, julgados conforme o cumprimento das normas e valores compartilhados por membros do grupo e verificáveis através da vox media, traduzem-se em variadas consequências sociais e jurídicas.

Em seu aspecto especificamente processual, a noção de "fama" - entendida como a qualidade de notoriedade de uma pessoa acusada de um crime, aferível por testemunhas com prestígio social (FIORI, 2012; KELLY, 2013) - funciona como uma motivação e impulso extraordinários suficientes para desencadear a investigação e persecução criminal ex officio (FIORI, 2012). Assim, conforme Kelly (2013, p. 9): 
suspect is widely held to be guilty of the specific crime that is being prosecuted. In other words, he has already been convicted in the court of public opinion. ${ }^{23}$

Não se sabe exatamente como era verificada a qualidade das testemunhas da notoriedade do acusado, nem quantas eram necessárias para que se considerasse determinado fato como "fama" pública. Havia certo dissenso entre os especialistas tardomedievais, que citavam números entre dez, duas, ou mesmo uma pessoa, desde que de confiança (FIORI, 2012). Em verdade, segundo avalia Migliorino (2016), a "fama" era mais um recurso argumentativo moldável nas mãos dos intérpretes dentro do fenômeno jurídico do que termo técnico.

O uso da "fama" como figura processual, registrada desde o final do século XII e início do século XIII em casos eclesiásticos, parece inerente ao processo inquisitorial, ${ }^{24}$ fazendo as vezes de representação fictícia do acusador para fins de instauração da inquisição (DAMAŠKA, 2012). Falava-se, nesse aspecto, na "fama" como substituição da voz do acusador, motivando a persecução penal de ofício (KELLY, 1989; FIORI, 2012). ${ }^{25}$ O artifício também servia como justificativa, ilusória é verdade, para a confusão entre julgador e acusador. Antes de iniciar o processo, o juiz realizava uma pesquisa preliminar que justificasse a persecução criminal. Caso a "fama" fosse comprovada, então convocaria o acusado e daria seguimento ao processo (THÉRY, 2003; KELLY, 2013). Verifica-se, portanto, que a "fama" ocupa papel central na justificação do processo inquisitorial, sendo requisito para sua adoção.

No caso de Joana D’Arc, apesar das interpretações no sentido de que o bispo Cauchon e os demais assessores teriam considerado a reputação internacional de Joana suficiente para o início do processo (KELLY, 2014), verificaram-se diligências investigativas preliminares com a finalidade de se estabelecer a "fama" da acusada. No dia 9 de janeiro de 1431, há registro de um primeiro encontro entre grupo de assessores para a escolha do procedimento a ser adotado. Na ocasião, Cauchon teria sido aconselhado a reunir, antes

\footnotetext{
${ }^{23}$ Tradução nossa: "Um requisito muito importante para se iniciar uma inquisitio era a publica fama, igualmente mal entendida por muitos estudiosos, os quais acreditam que se refere à má reputação geral de um suspeito. O que ela realmente significa é que certo suspeito é amplamente tido como culpado do crime específico que está sendo perseguido. Em outras palavras, ele já foi condenado no tribunal da opinião pública".

${ }^{24}$ A "fama" como motivação para instalação de uma inquisitio surge, dentro direito canônico, junto à própria oficialização da inquisitio no cânone n. 8 do IV Concílio de Latrão, intitulado "Qualiter et Quando", em 1215. Conforme o referido cânone, editado pelo papa Inocêncio III, irregularidades cometidas por clérigos e constatadas por "clamorem et famam" deveriam ser verificadas de ofício por seus superiores eclesiásticos, sem a necessidade de um acusador (FRAHER, 1992).

25 Théry (2003) mostra como, a partir de sua adoção processual no pontificado de Inocêncio III, a "fama" operava como importante mecanismo de controle eclesiástico pelo papa e de centralização da Igreja.
} 
do início do processo, informações sobre ações e palavras atribuídas a Joana (HOBBINS, 2005), ao que teria então ordenado a realização de investigações em seu vilarejo de origem e em outros lugares. Os resultados da busca foram apresentados em 13 de janeiro de 1431, fornecendo base para a redação de um primeiro grupo de artigos de acusação (HOBBINS, 2005), ${ }^{26}$ os quais serviriam de guia para um primeiro interrogatório. Em 23 de janeiro, após a leitura desses artigos, Cauchon ainda ordenara nova investigação sobre as ações e falas da acusada (HOBBINS, 2005). ${ }^{27} \mathrm{O}$ resultado dessas investigações e o conteúdo dos primeiros artigos, contudo, não aparece nos registros e também não constam do posterior processo de reabilitação (HOBBINS, 2005).

Embora não haja registros dos resultados desses questionamentos preliminares, 0 que dificulta saber como se configurou a "fama" que teria embasado a acusação formal de Joana, pode-se destacar dois aspectos dos procedimentos adotado nessas investigações que podem servir para ilustrar o uso político das formas processuais.

Primeiramente, o procedimento não escapara da exigência do cumprimento de requisitos processuais necessários para se justificar a citação de Joana. É o que nos parece pela leitura dos registros dos dias 13 de janeiro, quando se ordenou a realização do inquérito preliminar na vila natal de Joana e em outras localidades, ${ }^{28}$ e do dia 19 de fevereiro, quando o bispo Cauchon e seu conselho, após a leitura dos artigos escritos com base nos depoimentos colhidos, consideraram os resultados suficientes para que Joana fosse citada a "responder a determinadas perguntas em matéria de fé" (HOBBINS, 2005, p. 35). ${ }^{29}$ A busca

26 "We further ordered the reading of evidence collected about this woman in her birthplace and in many other places, as well as specific notes on this evidence and on other things that were commonly reported. The masters then decided that articles should be drafted in due form, that we might arrive at a clearer understanding of the case so ordered, and that we might be more certain whether the evidence was sufficient to summon anyone in a trial of faith". Tradução nossa: "Em seguida, ordenamos a leitura da evidência coletada sobre essa mulher em seu local de nascimento e muitos outros lugares, bem como notas específicas sobre essa evidência e sobre outras coisas que eram comumente reportadas. Os mestres então decidiram que os artigos deveriam ser redigidos na devida forma, para que pudéssemos chegar a um entendimento mais claro do caso em questão e para que pudéssemos estar mais certos se a evidência era suficiente para citar alguém em um julgamento de fé". A exigência de convocação formal à corte, chamada de citatio, é apresentada por DAMAŠKA (2012) como regra essencial do processo inquisitorial lastreada em um direito natural. Também sobre a citação, v. nota 21 , supra.

27 "They replied that the articles had been gathered and drafted in good and proper form, that a formal set of questions corresponding to the articles should be drawn up, and that we the bishop should proceed to gather information about the words and actions of the prisoner". Tradução nossa: "Eles responderam que os artigos foram colhidos e redigidos em boa e adequada forma, que um conjunto formal de perguntas correspondente aos artigos deveria ser elaborado, e que nós, o bispo, deveríamos proceder para juntar informações sobre as palavras e ações da prisioneira".

${ }^{28}$ Ver nota 26 supra.

${ }^{29}$ Conforme descrito no processo, o objetivo da pesquisa preliminar era "to determine whether there was sufficient cause to summon this woman in a trial of faith". Tradução nossa: "determinar se havia causa suficiente para citar essa mulher em um julgamento de fé". Após a leitura dos artigos e colheita de testemunhos, sob o conselho dos juristas, relata-se que "on their advice, we decided that we had sufficient 
de cumprimento da exigência assume especial relevância quando contextualizamos a figura jurídica com seu papel justificador do processo inquisitorial. Desse modo, ao garantir a comprovação da "fama" sobre os crimes de Joana, justificou-se a adoção de um modelo processual carente de figura acusatória autônoma e sem os riscos simbólicos que um processo judicial por accusatio ou mesmo uma execução sumária da ré poderiam trazer: conectar a condenação de Joana à atuação de seus inimigos políticos. Antes, por se tratar de julgamento de heresia, competência eclesiástica ex ratione materiae, o processo foi dirigido oficialmente por um bispo e um vice-inquisidor, representantes da Igreja Católica, instituição responsável pelo julgamento de todos os cristãos em matérias de fé. ${ }^{30}$

Em segundo, a investigação preliminar da "fama", pelo menos no processo de Joana, parece conectada à própria construção da acusação, visto que diversas perguntas da primeira fase do interrogatório, bem como os primeiros artigos de acusação, foram formuladas com base nas pesquisas prévias sobre a vida, os hábitos e a relação da acusada com sua vila natal. Como exemplo, pode-se citar a pergunta feita para Joana na terceira sessão de interrogatório, em 24 de fevereiro, sobre uma árvore e uma fonte na região de Domrémy, famosos na vila por se suporem frequentados por fadas. Na sessão, Joana afirma que realmente andava pelo local, mas que nunca observou nada parecido; diz, contudo, que havia boatos espalhados na comunidade segundo os quais ela recebeu suas famosas visões perto da árvore, mas que estes eram falsos (HOBBINS, 2005). Esse episódio é citado posteriormente nos artigos $5^{\circ}$ e $6^{\circ}$ da acusação, os quais acusam Joana de realizar rituais perto da referida árvore e, implicitamente, de entrar em contato com fadas e outros seres sobrenaturais (HOBBINS, 2005), referindo-se aos depoimentos colhidos anteriormente.

Interessante notar, portanto, a preocupação dos inquisidores com a regularidade procedimental desde o início do processo, destacada pela verificação preliminar da fama de Joana - inclusive porque, à época, em virtude de mudanças trazidas pelo papa Bonifácio VIII, já havia opiniões que julgavam dispensável a demonstração da "fama" por meio de testemunhas, tais quais a de Panormitano em seus comentários à Liber Extra, redigidos em 1436 (KELLY, 2014). Os registros inquisitórios do bispo Jacques Fournier, realizados no começo do século XIV, mostram, por exemplo, processos em que a "fama" foi simplesmente atestada pelo juiz, sem colheita específica de depoimentos (INQUISITION..., ca. 2006).

evidence to justify summoning this woman, and we ordered her called and summoned on a matter of faith to answer certain questions". Tradução nossa: "sob seus conselhos, decidimos que havia evidência suficiente para justificar a citação dessa mulher, e ordenamos que ela fosse chamada e citada em matéria de fé para responder a certas perguntas".

30 Sobre a competência dos tribunais eclesiásticos, ver: Lopes (2011a, p. 84-86). 
Assim, a possibilidade que se formula é que a pesquisa preliminar foi realizada justamente para se evitar questionamentos sobre a validade do processo e para justificar a adoção do processo inquisitório, além de auxiliar o juiz-inquisidor na elaboração de perguntas e acusações e facilitar a persecução penal.

O que se enxerga, portanto, é uma busca de cumprimento do requisito processual da "fama" para tentar proteger o processo de posteriores críticas trazidas aos julgadores, especialmente considerando a atenção internacional que o julgamento de Joana havia atraído à época (HOBBINS, 2005). Aqui, a influência política nas formas parece ter agido para provocar um maior rigor processual dos juízes, e não para flexibilizar o andamento do processo, o que se coaduna com nossa tese de que o caráter político do processo independe de violações processuais.

\section{O momento de apresentação das acusações nos processos inquisitoriais e a antecipação do interrogatório de Joana D'Arc}

Outra questão que sobressai em uma análise processual do julgamento de Joana D'Arc é a do momento e os requisitos exigidos para a apresentação das acusações. Ordinariamente, a verificação da "fama" e a apresentação dos artigos de acusação pelo libellus (instrumento escrito de acusação) deveriam ser feitos antes do início do interrogatório. Ao menos era a posição de parte dos canonistas, a exemplo do que aparece nos Comentários de Hostiensis em 1271, a quem tais atos seriam requisitos para o interrogatório do réu pelo juiz, sob pena de invalidade do próprio julgamento (KELLY, 1993).

A sanção de nulidade processual foi, todavia, tratada de maneira flexível por meio de um decreto papal, condicionada a uma espécie de regime preclusivo. Em 1298, Bonifácio VIII, em dois decretos editados por ocasião da compilação Liber Sextus, acrescentou àquela regra a ressalva de que a invalidação do interrogatório ou do julgamento dependiam da impugnação do acusado durante a realização do ato, não posteriormente. Na explicação de Kelly (1993, p. 996-997):

Pope Boniface VIII in his Liber sextus of 1298 countered this position with two new laws. In Postquam he said that if you confess to a crime in an inquisition, you cannot invalidate your confession by claiming that you were never defamed of the crime or that charges were not presented to you. In Si is he said that if you are summoned to an inquisition and the judge proceeds to the business of inquiring into the truth of the 
charges without first establishing fame, if you are present and do not object, you cannot later impugn the trial on that basis. ${ }^{31}$

As duas hipóteses se referem, basicamente, à confissão de um crime durante um interrogatório sobre acusações do qual o acusado, ora confesso, não teria sido informado e, segundo, à realização de um interrogatório sem a prévia aferição da fama do acusado.

O mesmo papa ainda autorizou oficialmente a aplicação de um procedimento de tipo sumário aos processos de heresia, o qual, gestado nos séculos XIII e XIV, dispensaria a apresentação escrita de um libellus e outras figuras processuais meramente dilatórias (INIESTA; CORETTI, 2019)

Não era, contudo, simples ao acusado manifestar-se durante os julgamentos. Para além da incompreensão técnica dos termos e da liturgia praticados, havia sempre o risco de incorrer em confissão em relação aquelas acusações ou outras quaisquer. À época, afirmações ou reconhecimento de fatos feitos durante processos de investigação eram automaticamente consideradas confissões notórias, dispensando qualquer prova adicional. Nos processos relativos a heresia, opiniões ou crenças expressas no julgamento poderiam constituir novos crimes, diferentes daqueles da acusação inicial.

O dilema do acusado desinformado acerca do que se the acusavam era entre arguir a invalidade do procedimento ou silenciar-se para ter o risco de piorar a sua situação. Como explica Kelly (1993, p. 992-993):

Remaining silent before being formally charged was especially important in heresy cases, because one could be convicted not only for confessing a previously committed crime but also for expressing an opinion or belief that could be taken as a brand-new crime of false belief; it would become instantly notorious and require no further proof simply by being uttered in court. ${ }^{32}$

Apesar de camponesa humilde, Joana optou pelo protesto contra a falta de informação sobre as acusações (registro de 24 de fevereiro), requerendo que lhe fossem

\footnotetext{
31 Tradução nossa: "Papa Bonifácio VIII, em sua Liber Sextus de 1298, combateu essa visão com duas novas leis. Em Postquam ele disse que, se alguém confessa um crime em uma inquisição, não pode invalidar sua confissão alegando que a fama nunca foi aferida ou que as acusações não lhe foram apresentadas. Em Si is, ele disse que, se alguém é citado em uma inquisição e o juiz procede à inquirição sobre a verdade das acusações sem antes estabelecer a fama, estando presente o suspeito e não apresentando objeção, não pode impugnar posteriormente o julgamento com base nisso".

32 Tradução nossa: "Permanecer em silêncio antes de ser formalmente acusado era especialmente importante em casos de heresia, visto que alguém poderia ser condenado não somente por confessar um crime cometido anteriormente, mas também por expressar uma opinião ou crença que poderia ser tomada como um novo crime ou falsa crença; este se tornaria instantaneamente notório e não exigiria prova adicional, simplesmente por ser proferido em corte".
} 
apresentados os pontos escritos pelos quais os juízes gostariam de interrogá-la. ${ }^{33}$ Seria, portanto, possível aplicar-se a regra de Bonifácio e considerar inválidas as afirmações de Joana feitas até então, o todavia que não foi feito. Destaque curioso nesse aspecto é que, como advogado em um caso anterior, o ora inquisidor Cauchon havia feito uso da regra para alegar vício processual semelhante (KELLY, 2014).

Um outro aspecto reforçava a nulidade processual. O processo de Joana sofreu uma divisão incomum entre processo em "preparatório" e "ordinário", o que fez com que a prisioneira fosse interrogada de 21 de fevereiro a 25 de março no bojo do primeiro sem que Ihe fossem informadas as acusações formuladas contra si até o início do segundo. ${ }^{34}$ Apenas em 28 de março lhe foi lido o libellus, 70 artigos que tiveram como base principalmente as pesquisas e interrogatórios iniciais (HOBBINS, 2005).

Ademais, esse libellus fora inteiramente reformulado a partir dos depoimentos colhidos na investigação. Como se tratavam de informações ditas em corte e sob juramento, eram considerados fatos notórios e podiam, inclusive, constituir novos crimes. A acusação foi reorganizada em 12 novos artigos (HOBBINS, 2005), os mesmos que, posteriormente, foram enviados à Universidade de Paris para a elaboração dos pareceres que, afinal, subsidiaram a condenação de Joana por heresia.

A hipótese formulada por alguns autores é de que a divisão do julgamento em processo preparatório e ordinário foi pensada posteriormente, durante o curso do processo, após o questionamento feito por um jurista de que o interrogatório havia começado sem a

\footnotetext{
${ }^{33}$ Kelly (1993) explica que há aqui uma diferença entre as versões em francês e em latim, a qual pode ser intencional para alterar o propósito do pedido de Joana. Enquanto no francês parece que Joana pede que lhe sejam informadas todas as acusações e perguntas trazidas contra ela, no latim o pedido parece mais restrito, somente dos pontos já perguntados aos quais ela não estava respondendo.

${ }^{34}$ Em seu mandado de citação, diz-se apenas que ela é citada "[...] to appear before us in the royal chapel of the castle of Rouen at eight o'clock in the morning of Wednesday, February 21, to answer the truth to the articles and questions and to other accusations, and to be dealt with according to law and reason". Tradução nossa: "para aparecer perante nós na capela real do castelo de Rouen às oito horas da manhã de quartafeira, 21 de fevereiro, para responder a verdade sobre os artigos, perguntas e outras acusações, e para ser tratada conforme a lei e a razão". Ao aparecer em audiência, do mesmo modo, é dito a Joana somente que "[...] after considering the common report and public rumors, as well as the reliable information mentioned above, and after mature counsel with experts in canon and civil law, we ordered that this Joan be summoned in writing to answer truthfully the questions put to her in matters of faith, and that she act according to law and reason, as set forth in letters shown by the promoter" (HOBBINS, 2005, p. 48-49). Tradução nossa: "após considerar os relatos comuns e rumores públicos, assim como a informação confiável acima mencionada, e após o aconselhamento maduro de especialistas em direito canônico e civil, ordenamos que essa Joana fosse citada por escrito para responder honestamente às questões postas em matérias de fé, e que ela agisse de acordo com a lei e a razão, como estabelecido nas cartas apresentadas pelo promotor".
} 
devida apresentação do libellus a Joana (HOBBINS, 2005) ${ }^{35}$ e com o objetivo de conferir aparência de regularidade ao procedimento.

Não obstante a discussão, razões que poderíamos hoje identificar como de pragmatismo eram usadas por outros inquisidores para flexibilizar a regra da anterioridade da apresentação das acusações. Como recomendavam manuais práticos de inquisidores famosos, como os de Bernard Gui e Nicolas Eymerich (KELLY, 1993), a realização do inquérito antes da apresentação das acusações nos casos de heresia justificava-se na dificuldade da prova de um crime como tal, "de pensamento". A antecipação da inquirição do acusado, ainda que "irregular", servia para compor os artigos de acusação posteriormente apresentados - exatamente o que aconteceu no caso de Joana.

Essa parecia ser uma prática comum. Além do verificado nos citados manuais práticos de inquisidores, que deveriam informar também sua atuação judicial, os registros da inquisição de Jacques Fournier, realizada no sul da França ao começo do século XIV, mostram a rotina de coletar depoimentos prestados sob juramento antes da apresentação da acusação ao suspeito (KELLY, 1993). Casos semelhantes podem ser encontrados, conforme informa Kelly (1993), em processos inquisitoriais por heresia coordenados entre 1428 a 1431 na diocese de Norwich, Inglaterra, em datas próximas às do julgamento de Joana.

Em suma, mesmo que pudesse ser dito que havia uma "limitação normativa formal" à realização do interrogatório sem apresentação das acusações, o caso de Joana D'Arc não parece tão diferente, nesse aspecto processual, da prática judiciária adotada à época do julgamento para crimes similares. Como lembrado no início, as regras do direito canônico, conquanto estabelecidas pela cúria papal, conviviam em um ambiente de pluralismo jurídico com outras tantas regras e, no caso, práticas judiciárias. ${ }^{36} \mathrm{~A}$ legitimidade do costume judiciário talvez explique a ausência de registros de impugnações à irregularidade formal por quase nenhum dos partidários contemporâneos de Joana, ${ }^{37}$ nem no julgamento de nulificação ocorrido posteriormente (HOBBINS, 2005), até porque, como dito, a cultura jurídica da época permitia flexibilizações maiores em casos de crimes tais quais o de heresia, marcado pelo profundo interesse social.

Portanto, embora cause estranheza ao olhar moderno, a ordem processual seguida não aparentava como antijurídica no ordenamento medieval, pelo menos no que se refere

\footnotetext{
35 Jean Lohier, que, segundo depoimento do notário Guillaume Manchon, estava de passagem por Rouen no ano de 1431. O depoimento foi colhido no processo de nulificação do julgamento de condenação.

${ }^{36}$ Ver nota 3 supra.

37 O único contemporâneo, em verdade, a argumentar pela irregularidade do julgamento pela ausência de apresentação das acusações a Joana foi o já citado Jean Lohier (KELLY, 2014). Ver nota 35 supra.
} 
aos julgamentos criminais de heresia. Por outro lado, parece plausível a hipótese de que a escolha de julgar Joana por esse crime específico e não por qualquer outra acusação conectada a sua atuação na guerra foi feita de maneira estratégica e permitiu a adoção de práticas e atalhos processuais que eram observados em outros casos semelhantes.

\section{Instrumentos de defesa: advogados e recursos}

O processo romano-canônico inquisitorial admitia a representação dos acusados por advogados de defesa, considerados inclusive, segundo interpretação da época, condição para o regular andamento dos processos criminais (ULLMANN, 1988, p. 481-489 apud LOPES, 2011a, p. 94). Sua presença, contudo, era mais comum nos casos de réus com prestígio social e, ainda assim, com atuação limitada na defesa de acusados de heresia como Joana (DAMAŠKA, 2012).

Estudos históricos revelam que a presença dos advogados era muitas vezes vista como obstáculo ao desenrolar dos processos (PETERS, 1988). O julgamento de crimes de heresia seguia o "procedimento sumário", variação ritual ratificada pela Igreja nos séculos XIII e XIV que despia o acusado de certos instrumentos de defesa em prol da rapidez do processo (DAMAŠKA, 2012; INIESTA; CORETTI, 2019). ${ }^{38}$

A impugnação de decisões tomadas nos processos, geralmente dirigida ao Papa, também não parecia comum nos processos de heresia e, tal qual a defesa por advogados, era considerada mais um foco de atraso nos julgamentos. Segundo os intérpretes, a regra vigente era a de que os recursos poderiam ser interpostos contra decisões "interlocutórias", como as que acolhem provas ou determinam o uso da tortura, ou contra as sentenças. Os recursos deviam ser apresentados por escrito e poderiam envolver a ida do réu à Roma ou a designação de uma investigação in loco (HILL, 2019). Manuais de inquisidores consideravam-nos um atraso ao processo e fonte de complicações práticas e políticas em seu desdobramento, o que talvez explique serem inadmitidos sem maiores explicações (HILL, 2019). ${ }^{39}$

No processo de Joana D'Arc, não há registro de participação de advogados em sua defesa, nem de questionamento da acusada sobre este ponto; também não há registro dessa

\footnotetext{
38 Dizia-se que o processo deveria proceder de maneira simples, sem o barulho de advogados e figuras jurídicas desnecessárias (DAMAŠKA, 2012).

39 O maior exemplo dessa atitude pode ser visto no manual e na prática judicial de Bernard Gui, onde se observa uma visão do recurso como instrumento para retardar ou reverter a atividade inquisitorial. O inquisidor sustenta, assim, que o juiz não deve acatar recursos e apelos suspeitos (HILL, 2019). Não obstante, apesar de lamentados pelos inquisidores, os recursos parecem ter adquirido, com o tempo, certa importância institucional, de modo que se tornaram mais frequentes durante o século XIV, como observado por Hill (2019).
} 
discussão no processo póstumo de nulificação (KELLY, 2014). A única objeção encontrada é a de um certo Jean Lohier, jurista que estava de passagem por Rouen à época do julgamento e criticou que os primeiros interrogatórios estavam sendo feitos sem o acompanhamento de advogados, tratando-se a acusada de pessoa simples e iletrada (KELLY, 2014).

Em verdade, após essa intervenção, na seção de 27 de março de 1431, já dentro do chamado processo ordinário e logo antes da leitura dos artigos de acusação, os juízes ofereceram a Joana que escolhesse um ou mais dos assessores presentes, "clérigos instruídos em direito canônico e civil", para auxiliá-la na defesa e na escolha do que "fazer ou responder" diante das acusações, justamente porque a acusada não era instruída nas letras e nas difíceis matérias discutidas. E, caso a ré não soubesse escolher, ainda lhe foi oferecido que os juízes apontassem um assessor em seu nome (HOBBINS, 2005). ${ }^{40}$ Joana simplesmente agradeceu e respondeu que não pretendia se afastar do conselho de Deus, recusando a oferta, ao que prosseguiu o processo sem advogado de defesa. ${ }^{41}$

De qualquer modo, embora Kelly (1989) argumente que a solução encontrada por Cauchon teria sido insuficiente pelo fato de que o bispo e seus assessores seriam inimigos políticos de Joana, parece que a saída de simplesmente oferecer a assessoria jurídica mas, diante da negativa da ré, conduzir o processo sem advogado de defesa foi aceita pelos contemporâneos de acusada, que, como dito, não apresentaram objeções à época do processo póstumo de nulificação (KELLY, 2014). Novamente, aqui parece haver uma tentativa por parte dos juízes de proteger o julgamento de críticas e garantir sua legitimidade.

Quanto aos recursos, os autos indicam que Joana requereu expressamente, de forma oral e após a leitura das sentenças nas sessões de 17 de março e de 2 e 24 de maio, que ela própria fosse levada ao Papa (HOBBINS, 2005). ${ }^{42}$ Seu último apelo foi negado sob

\footnotetext{
40 "And since she was not sufficiently learned and instructed in letters and such difficult matters to serve as her own counsel about what to say or do, we therefore suggested that she choose one or more of the assessors present; or, if she knew not how to choose, we could appoint some of them to counsel her about what to do or reply, it being understood that she would have to speak truthfully for herself about her conduct" (HOBBINS, 2005, p. 122). Tradução nossa: "E visto que ela não era suficientemente estudada e instruída em letras e tais difíceis matérias para aconselhar-se sobre o que falar o fazer, nós sugerimos que ela escolhesse um ou mais dos assessores presentes; ou, caso não soubesse como escolher, nós poderíamos apontar alguns deles para aconselhá-la sobre o que fazer ou responder, sendo compreendido que ela deveria falar honestamente por si sobre sua conduta".

${ }^{41}$ A resposta de Joana foi registrada como segue: "First, I thank you and the entire assembly for advising me on my own welfare and on our faith. I thank you also for the counsel you offer. But I don't intend to depart from the counsel of God." (HOBBINS, 2005, p. 122). Tradução nossa: "Primeiramente, eu Ihe agradeço e a toda a Assembleia por me aconselhar sobre meu próprio bem-estar e nossa fé. Também agradeço pela assessoria que oferece. Mas não pretendo me afastar do conselho de Deus".

${ }^{42}$ Após a leitura de sua sentença, Joana diz: "As for submitting to the Church, I already answered them on this point: let everything l've said and done be reported to Rome, to our holy father the pope, to whom I yield after God" (HOBBINS, 2005, p. 191). Tradução nossa: "Quanto a submeter-se à Igreja, eu já Ihes respondi
} 
os fundamentos de que isso seria impossível e que os bispos locais eram seus juízes competentes (HOBBINS, 2005). Hobbins (2005) ainda sustenta a existência de outros possíveis motivos para a negativa, relacionados ao fato de que Joana era uma prisioneira da Inglaterra e de que haveria disputas de autoridade envolvendo Roma e os bispos.

Mesmo assim, a impugnação de decisões judiciais parece ter se incorporado ao processo inquisitorial adotada na época (HILL, 2019). O próprio bispo Cauchon, em anterior atuação como advogado, teria argumentado pela sua interposição (KELLY, 2014). A não admissão do pedido de Joana de ser ouvida pelo Papa foi uma das impugnações à regularidade procedimental levantadas no julgamento póstumo de reabilitação de Joana (HOBBINS, 2005).

Ainda assim, formula-se a mesma hipótese de uma atuação estratégica da parte dos julgadores de Joana, os quais, optando por persegui-la pelo crime de heresia, permitiram a flexibilização de algumas exigências processuais cuja adoção era relativizada em hipóteses semelhantes. Como se viu, os processos de heresia permitiam uma atuação do juiz mais preocupada com a eficiência da punição criminal do que com formalidades, instrumentos de defesa e revisão das decisões, adotando-se o chamado procedimento sumário, o que transparecia nos manuais inquisitoriais. Em casos como o de Joana, nos quais o réu não possuía nenhuma qualificação social importante, isso aparenta ser mais provável ainda.

\section{Instrumentos probatórios: confissão e tortura}

O final do século XII e início do século XIII registram uma revolução nas formas de julgamento, capitaneada pelo processo eclesiástico. A redescoberta do inquérito como procedimento de investigação racional da verdade substituiu o sistema de provas de força, de sorte e de prestígio social (FOUCAULT, 2011). A abolição dos ordálios coincide com a sedimentação do processo inquisitorial (FRAHER, 1992). O julgamento de Joana D'Arc acompanha e serve para ilustrar esse contexto de transformações no modelo processual europeu medieval.

O inquérito, elemento catalisador dessas mudanças, é recuperado para instrumentalizar os processos administrativos internos da Igreja Católica (FOUCAULT, 2011). Com a possibilidade da demonstração racional do conjunto de fatos que ilustravam

sobre esse ponto: deixem tudo o que disse e fiz ser reportado a Roma, a nosso santo padre, o Papa, a quem eu me submeto depois de Deus". 
as acusações, aquele modelo de julgamentos precisou diferenciar a eficácia dos diversos tipos de provas.

Com a abolição dos ordálios, a doutrina romano-canônica desenvolveu um complexo sistema de provas tarifadas, que funcionavam de maneira quase matemática: falava-se em indícios, provas semiplenas, plenas e fatos notórios (LOPES, 2011a), tabeladas segundo graus de convencimento e eficácia como fundamento dos julgamentos.

A despeito da sua pretensão de objetividade, o sistema de provas tarifadas do ius commune não era tão rígido quanto aparentava (FRAHER, 1989a). Os debates registrados nos séculos XIII ao XVI apontam haver diversos mecanismos para que o juiz subvertesse as provas tarifadas e chegasse a uma condenação sem a "prova plena", difícil de se alcançar.

O sistema de provas tarifadas serviu, paralelamente, para reafirmar o valor da confissão para os julgamentos. Uma vez dita em corte, a confissão constituía fato notório capaz de fundamentar, quase sozinha, o convencimento do julgador, o que era especialmente útil na ausência de testemunhas capazes de constituir a prova plena (PETERS, 1996). Como sintetiza Foucault (1999, p. 57), no direito medieval "a confissão torna a coisa notória e manifesta".

A confissão possuía importância específica nos processos de heresia, em diferentes dimensões. Pela abjuração ou arrependimento - ato pelo qual o réu reconhece o desvio de fé e promete não mais errar (HILL, 2019) -, ela assumia a face penitencial das inquisições, em que o inquisidor é, além de força política, figura espiritual incumbida de salvar as almas dos hereges e reconduzi-los à Igreja. ${ }^{43}$ Por outro lado, a confissão servia como legitimadora da verdade, fazendo com que o próprio acusado reconhecesse seu crime e a fundamentação da acusação. "[P]ela confissão, o próprio acusado toma lugar no ritual de produção de verdade penal" (FOUCAULT, 1999, p. 57). A confissão ainda servia para definir as penas a serem aplicadas ao condenado: se herege arrependido (penitente), não era comum a pena capital; contudo, se o réu se recusa a abjurar (é impenitente), ou abjura e depois incorre no mesmo erro (é relapso), a pena capital era de regra aplicada (HILL, 2019; PETERS, 1988).

A tortura judicial surge, diante desse quadro, como prática cada vez mais comum nos processos inquisitórios. Recuperada como instituto previsto no processo romano, ${ }^{44}$ foi

\footnotetext{
${ }^{43}$ Sobre as fundações espirituais, teológicas e penitenciais da inquisição, ver: Ames (2019).

44 Ulpiano já apresentava definição bem clara da tortura judicial no Digesto, chamada de tormento ou quaestio, como "a submissão do corpo à dor com o objetivo de se descobrir a verdade", conceito adotado pelos juristas medievais (PENNINGTON, 2008, p. 05).
} 
expressamente permitida nas cortes eclesiásticas pelo Papa em 1252 (PETERS, 1996; EICHBAUER, 2014) e ganhou então importância por sua capacidade de extrair declarações do réu que, consideradas então como confissão, eram suficientes para fundamentar os julgamentos (PETERS, 1996).

A tortura também reforçava a figura do inquisidor como defensor do interesse público, o que lhe permitiria recorrer a meios extraordinários para a descoberta da verdade nos julgamentos (ULLMANN, 2009).

As hipóteses de utilização da tortura, contudo, não eram bem definidas. Alguns inquisidores consideravam-na último recurso de prova, cabível apenas após a utilização dos outros meios possíveis enquanto outros adotavam-na como ferramenta ordinária no curso do processo (HILL, 2019; PETERS, 1996). Os indícios que serviam para desencadear o recurso à tortura também eram discutíveis, a despeito dos esforços de se sistematizar as hipóteses específicas nas quais poderia ser utilizado - como exemplo, o manual do inquisidor Eymerich (HILL, 2019).

Por último, como destaca Pennington (2008), mesmo fazendo parte do processo jurídico da época, a tortura não era vista pela comunidade jurídica medieval como meio confiável para extração de informações dos acusados. Não se desconsiderava que ela poderia levar a condenações equivocadas, o que sugeria uso parcimonioso pelos tribunais.

No processo de Joana, a despeito da alusão a depoimentos colhidos na fase inicial, não houve o recurso a provas testemunhais (HOBBINS, 2005). Os 12 últimos artigos da acusação são baseados predominantemente nas afirmações feitas pela própria Joana nos interrogatórios. Já o processo de nulificação posterior, diferentemente, baseou-se fortemente em testemunhos. Essa diferença parece significativa.

Apesar do processo inquisitorial admitir a condenação baseada exclusivamente na confissão, mesmo se obtida em um interrogatório sobre acusações desconhecidas ou por meio de tortura, o padrão probatório adotado no julgamento de Joana mostra-se, como observa Peters (1988), diferente da prática inquisitorial da época, particularmente por não haver, segundo os registros, oitiva de testemunhas.

Em dois momentos do processo de Joana, o tribunal cogitou o uso da tortura. Em ambos, decidiu-se pela não utilização. Após o recebimento dos pareceres sobre os artigos de acusação - geralmente no sentido de considerá-la culpada por heresia (HOBBINS, 2005) -, os juízes provocaram a abjuração de Joana, ato que traria implicações práticas para a instrução probatória e para a sentença, como discutido acima. Eles resolveram que 
um certo mestre em teologia deveria instruí-la de seus erros e alertar-lhe para a possibilidade de salvação de seu corpo e alma caso abjurasse (HOBBINS, 2005).

Joana permaneceu firme em suas opiniões, tanto naquele dia quanto em 9 de maio, quando o interrogatório teve continuidade. Nessa ocasião, fora-lhe dito que, se não confessasse a verdade das acusações, seria posta sob tortura. Foram-lhe mostrados os instrumentos do suplício (HOBBINS, 2005), performance simbólica destacável. Mantidas as duras respostas da ré, os juízes decidiram não aplicar a tortura até obterem maiores conselhos, justificando-se na sua pouca utilidade no caso (HOBBINS, 2005). ${ }^{45}$

Na sessão seguinte, do dia 12 de maio, o bispo Cauchon consultou 13 assessores, bem como o vice-inquisidor Jean le Maistre, quanto à adoção do expediente da tortura. Somente três manifestaram-se favoravelmente, justificando-se na busca da verdade ou na salvação de sua alma. O restante, contraindicando o uso da tortura, invocaram a desnecessidade diante da existência de outras evidências, bem como o medo de macular de irregularidade um julgamento até então "bem conduzido" (HOBBINS, 2005, p. 179-180). Ao final, decidiu-se não submeter Joana à tortura em razão da negação insistente da ré e das circunstâncias gerais do caso (HOBBINS, 2005). ${ }^{46}$

O processo prosseguiu com a coleta de novos pareceres e a oferta de novas explicações a Joana, que insistiu em manter suas falas anteriores e defender os atos pelos quais fora levada a julgamento - suas vozes e o uso de roupas consideradas masculinas (HOBBINS, 2005).

Em 24 de maio, iniciou-se a leitura de sua primeira sentença de condenação, a qual, ao que tudo indica, seguiria os pareceres apresentados e lhe entregaria ao braço secular ${ }^{47}$ por não ter demonstrado arrependimento (HOBBINS, 2005). O lastro probatório dessa

\footnotetext{
45 "Seeing the hardness of her heart and the tone of her answers, we the judges feared that the instruments of torture would profit her little, and decided not to apply them until we had further counsel on the matter". Tradução nossa: "Vendo a dureza de seu coração e o tom de suas respostas, nós juízes tememos que os instrumentos de tortura pouco adiantariam e decidimos não os utilizar até que tivéssemos mais aconselhamento sobre a matéria".

46 "After hearing their answers and considering what Joan had said that Wednesday, and after taking into account her attitude and will, and the circumstances of the case, we decided that it was inexpedient and unnecessary to put her to the torture, and that we would proceed to other matters". Tradução nossa: "Após ouvirmos suas respostas e considerarmos o que Joana havia dito nesta quarta-feira, e após levar em conta sua atitude e vontade, decidimos que era inadequado e desnecessário pô-la sob tortura, e que procederíamos a outros assuntos".

${ }^{47}$ Celebremente, no âmbito da Igreja Católica chamava-se a pena de morte de entrega ao braço secular pelo fato de que a Igreja não poderia aplicá-la, apesar de realizar a condenação.
} 
primeira sentença parece ter sido somente as falas da acusada no processo, como se observa pela leitura dos últimos 12 artigos de acusação (HOBBINS, 2005). ${ }^{48}$

Durante a leitura da sentença, todavia, Joana declarou que queria se arrepender, tendo lido e assinado uma fórmula de abjuração que lhe foi apresentada e na qual reconhecia as supostas heresias pelas quais era acusada, renunciava a suas visões e aceitava retornar para o "caminho da verdade" (HOBBINS, 2005). Diante da abjuração, proferiu-se nova sentença, reconhecendo o arrependimento da ré e condenando-a, desta vez, à prisão perpétua.

Nos dias seguintes, contudo, Joana voltou a utilizar roupas masculinas e a defender suas visões, ${ }^{49}$ afirmando não ter compreendido a fórmula de abjuração. Então, em uma derradeira sentença, foi considerada relapsa e condenada à morte (HOBBINS, 2005).

Hobbins (2005) levanta a hipótese de que a execução de Joana não era necessariamente desejada pelos seus juízes, que poderiam preferir a prisão perpétua autorizada pela abjuração - um desfecho, inclusive, mais danoso a sua reputação. Foucault lembraria, diante da hipótese, que a confissão é mecanismo de prova permite a legitimação da verdade pelo próprio acusado. O raciocínio explicaria a insistência dos juízes para que Joana se arrependesse e confessasse seus erros. No caso de Joana, entretanto, isso significaria a negação de suas vozes, do uso de roupas masculinas e, em última análise, da posição de que a vontade divina era partidária dos franceses na guerra, defendida pela ré ao longo de todo o processo.

Aqui, novamente, a estratégia de se acusar Joana pelo crime de heresia se manifesta em formas processuais específicas que contribuem para a legitimação de uma narrativa sobre a ré. Do mesmo modo, preferiu-se evitar o uso da tortura, o que também reforça a hipótese de que os juízes de Joana buscaram justificar e proteger o processo de possíveis críticas através de uma observância geral de regras processuais, considerando a desconfiança levantada pelo tormento e o receio expresso dos assessores.

\footnotetext{
${ }^{48}$ Redigidos em um formato de confissão, referem-se expressamente às afirmações da ré e ressaltam que ela persiste em erro, de modo que, diante da ausência de outras provas, os juízes parecem ter interpretados suas falas como confissões (HOBBINS, 2005)

49 Testemunho do processo de nulificação atribui o retorno às roupas masculinas a tentativas de estupro na prisão por um nobre inglês. Não obstante, como Hobbins (2005) argumenta, mesmo que isso seja verdade, Joana espontaneamente declarou que tinha voltado a acreditar nas vozes, tratando sua abjuração como um momento de fraqueza diante da sentença.
} 


\section{Considerações finais}

A análise de aspectos procedimentais do julgamento de Joana D'Arc oferece elementos para a compreensão mais clara do funcionamento da prática inquisitorial da época. Dentre as conclusões aventadas, parece emergir a de que não se tratava de um modelo processual desprovido de garantias processuais protetoras do réu, como se poderia argumentar a partir de uma perspectiva contemporânea, mas um modelo em que as garantias existentes eram tratadas com alta dose de flexibilidade.

Observa-se, por exemplo, que, a despeito da aferição da "publica fama" no início do processo, do oferecimento de assessoria jurídica e do não uso da tortura, o que indicam uma preocupação com a correção do processo para evitar possíveis críticas, o julgamento de Joana teria flexibilizado a ordem procedimental respectiva, iniciando-se o interrogatório da acusada antes de lhe expor os artigos de acusação e redigindo-se o libellus com base nessas perguntas preliminares. Tal prática era comum nos processos da época e aponta a predominância dos costumes sobre as prescrições contidas nos textos normativos. De modo similar, enquanto a ausência de advogados parece ter sido pouco questionada, a denegação da possibilidade de impugnação ao Papa das decisões proferidas pelo tribunal inquisitorial teve certa importância na anulação posterior do julgamento - embora também apresentasse dificuldades práticas.

Em verdade, a maleabilidade dos critérios que definiam um processo como devido ou adequado parece ser característica presente nos processos inquisitoriais. Como analisa Damaška (2012), aspectos de ordem social, como o prestígio social do acusado, mostramse relevantes, ao lado das normas e costumes existentes, para a opção de se manter ou não as regras processuais previstas e oferecer ou não garantias processuais ao acusado. Ainda é relevante mencionar que, especificamente tratando do crime de heresia, o qual representava importante ofensa ao interesse público na época, as regras e formalidades eram comumente flexibilizadas em nome da punição penal.

Dessa maneira, embora seja claro que o julgamento de Joana tenha sido conduzido de maneira a obter proveito político dentro do contexto da Guerra dos Cem Anos, isso não se reflete necessariamente em violações da ordem processual da época, a qual era marcada pelo casuísmo e pluralismo jurídico e desconhecia o princípio da legalidade conclusão defendida por Hobbins (2005). Afasta-se, assim, a interpretação de Kelly (2013), que vê no julgamento um constante desvio do direito canônico sem se atentar para as questões histórico-jurídicas preliminares. Mesmo no julgamento posterior, em um momento 
político completamente diverso, após o final da guerra e com ânimos mais favoráveis aos franceses, pouco se discutiu sobre supostas violações processuais, focando-se na reconstrução da vida e imagem de Joana através de prova testemunhal (PETERS, 1988).

O que se verifica é que, apesar de claramente político devido aos motivos já citados, o processo de Joana não se desvia muito da prática inquisitorial da época. O caráter político do julgamento, portanto, não se mostrou na violação direta regras processuais, mas envolveu justamente um uso estratégico das figuras e modelos de processo.

Nesse sentido, conforme relata Foucault (2011), o próprio nascimento do processo inquisitorial por inquérito tem motivação política, visto que conectado a mecanismos de poder da Baixa Idade Média e a necessidades de centralização administrativa da Igreja e dos Estados nascentes. Do mesmo modo, a escolha de julgar Joana através de um procedimento inquisitorial por heresia, coordenado por uma autoridade relevante e, pelo menos externamente, politicamente neutra como a Igreja Católica, representada pelos oficiais do julgamento, parece ter papel importante para a legitimação da narrativa de Joana como herege, buscando afetar a sua reputação.

O uso da figura da heresia, inclusive, contribuiu para a flexibilização de regras protetoras da ré em momentos como a apresentação das acusações, o uso de advogados, recursos e a instrução probatória, direcionando o julgamento à confissão e arrependimento de seus supostos erros, o que se obteve ao final (HOBBINS, 2005). Todos esses fatores se encaixam no argumento do uso político das formas de produção da verdade (FOUCAULT, 2011), de modo que a observação detalhada do processo fornece material para a melhor compreensão de como funcionavam, na prática, os mecanismos e as técnicas inquisitoriais, capilarizando o poder e contribuindo para a legitimação de uma certa noção de verdade.

Aqui, a análise da operação da corte, de como o processo se inicia, suas técnicas de interrogatório, seus instrumentos probatórios e do valor dado à abjuração mostra-se especialmente relevantes. Isso porque o estudo das ferramentas jurídicas, de sua aplicação e meios de uso, por mais técnico que possa parecer, encontra-se inserido também na compreensão de um processo (político) de persecução penal e produção da verdade, de modo que a análise das figuras procedimentais assume papel importante na compreensão do fenômeno social e jurídico da inquisição e, mais amplamente, no estudo das conexões existentes entre o processo judicial e o poder político. 


\section{Referências}

AMES, Christine Caldwell. The Spiritual Foundations of Christian Heresy Inquisitions. In: PRUDLO, Donald (Ed.). A Companion to Heresy Inquisitions. Leiden: Brill, 2019. p. 17-40.

ARAÚJO, Danielle Regina Wobeto de. Feitiçaria na vila de Curitiba: direito e misoginia (xviii). Revista Direito e Práxis, v. 10, n. 1, p. 222-249, jan./mar. 2019. http://dx.doi.org/10.1590/2179-8966/2018/31930

ARAÚJO, Danielle Regina Wobeto de; VALLE, Gabrielle Stricker do. Processo dos delitos e das heresias: um guia de leitura das Ordenações Filipinas (1603) e do Regimento Inquisitorial (1640). Porto Alegre: Fi, 2019.

CRANE, Susan. Clothing and Gender Definition: Joan of Arc. The Journal of Medieval and Early Modern Studies, v. 26, n. 2, p. 297-320, set./dez. 1996. Disponível em: http://faculty.smu.edu/bwheeler/joan_of_arc/olr/08_clothingjoanofarc_crane.pdf. Acesso em: 22 ago. 2020.

DAMAŠKA, Mirjan. The Faces of Justice and State Autorithy: a Comparative Approach to the Legal Process. New Haven: Yale University Press, 1986.

DAMAŠKA, Mirjan. The Quest for Due Process in the Age of Inquisition. The American Journal of Comparative Law, v. 60, n. 4, p. 919-954, out. 2012. Disponível em: https://www.jstor.org/stable/41721692. Acesso em: 23 ago. 2020.

EICHBAUER, Melodie. Medieval Inquisitorial Procedure: Procedural Rights and the Question of Due Process in the 13th Century. History Compass, v. 12, n. 1, p. 72-83, 2014. https://doi.org/10.1111/hic3.12130

FIORI, Antonia. Quasi denunciante fama: note sullintroduzione del processo tra rito accusatorio e inquisitorio. In: SCHMOECKEL, Mathias; CONDORELLI, Orazio; ROUMY, Franck (Org.). Der Einfluss der Kanonistik auf die Europäische Rechtskultur: Band 3: Straf - und Strafprozessrecht. Weimar: Böhlau Verlag, 2012. p. 351-368.

FONSECA, Ricardo Marcelo. La historia en el derecho y la verdad en el proceso: el argumento de Michel Foucault. In: Introducción teórica a la historia del derecho. Madrid: Dykinson, 2012. p. 113-134.

FOUCAULT, Michel. Vigiar e punir: nascimento da prisão. Tradução de Raquel Ramalhete. Petrópolis, RJ: Vozes, 1999.

FOUCAULT, Michel. Microfísica do poder. Tradução e organização de Roberto Cabral de Melo Machado. 23. ed. São Paulo: Graal, 2007.

FOUCAULT, Michel. A verdade e as formas jurídicas. Tradução de Roberto Cabral de Melo Machado e Eduardo Jardim Morais. 3. ed. Rio de Janeiro: Nau/PUC, 2011.

FRAHER, Richard. The Theoretical Justification for the New Criminal Law of the High Middle Ages: "Rei Publicae Interest, Ne Crimina Remaneant Impunita". University of Illinois Law Review, v. 36. n. 3, p. 577-596, jul./set. 1984. Disponível em: https://www.repository.law.indiana.edu/facpub/1854. Acesso em: 24 ago. 2020. 
FRAHER, Richard. Conviction According to Conscience: The Medieval Jurists' Debate Concerning Judicial Discretion and the Law of Proof. Law and History Review, v. 7, n. 1, p. 23-88, 1989a. https://doi.org/10.2307/743777

FRAHER, Richard. Preventing crime in the High Middle Ages. In: SWEENEY, James; CHODOROW, Stanley (Ed.). Popes, teachers and canon law in the Middle Ages. Nova York: Cornell University Press, 1989b. p. 212-233.

FRAHER, Richard. IV Lateran's Revolution in Criminal Procedure: The Birth of «Inquisitio», the End of Ordeals, and Innocent III's Vision of Ecclesiastical Politics. In: LARA, Rosalio José Castillo (Org.). Studia in honorem eminentissimi cardinalis Alphonsi M. Stickler. Roma: LAS, 1992. p. 97-111.

GROSSI, Paolo. Aequitas Canonica. Quaderni Fiorentini per la Storia del Pensiero Giuridico Moderno, n. 27, p. 379-396, 1998. Disponível em: http://www.centropgm.unifi.it/cache/quaderni/27/0380.pdf. Acesso em: 3 set. 2020.

GROSSI, Paolo. Mitologias Jurídicas da Modernidade. Tradução de Arno Dal Ri Júnior. Florianópolis: Boiteux, 2004.

GROSSI, Paolo. Primeira Lição sobre o Direito. Tradução de Ricardo Marcelo Fonseca. Rio de Janeiro: Forense, 2006.

HESPANHA, António Manuel. Cultura Jurídica Europeia: síntese de um milênio. São Paulo: Almedina, 2012.

HILL, Derek. Inquisition in the Fourteenth Century: the manuals of Bernard Gui and Nicholas Eymerich. New York: York Medieval Press, 2019.

HOBBINS, Daniel. The Trial of Joan of Arc. Cambridge: Harvard University Press, 2005.

INIESTA, Javier Belda; CORETTI, Michela. The sources of the procedural roman-canonical law before Clemens V. Glossae: European Journal of Legal History, v. 16, p. 50-76, 2019. Disponível em: http://www.glossae.eu/wp-content/uploads/2019/08/Belda-Coretti-Romancanonical-procedure-before-Clemens-V.pdf. Acesso em: 2 set. 2020.

INQUISITION Records of Jacques Fournier. Tradução de Nancy Stork, [ca. 2006]. Disponível em: https://www.sjsu.edu/people/nancy.stork/jacquesfournier/. Acesso em: 23 abr. 2020.

KELLY, Henry Ansgar. Inquisition and the Prosecution of Heresy: Misconceptions and Abuses. Church History, v. 58, n. 4, p. 439-451, dez. 1989. https://doi.org/10.2307/3168207

KELLY, Henry Ansgar. The Right to Remain in Silent: Before and After Joan of Arc. Speculum, Chicago, v. 68, n. 4, p. 991-1026, out. 1993. Disponível em: http://faculty.smu.edu/bwheeler/Joan_of_Arc/OLR/cr_Kelly_theright.pdf. Acesso em: 12 maio 2020.

KELLY, Henry Ansgar. Inquisition, Public Fame and Confession: General Rules and English Practice. In: FLANNERY, Mary; WALTER, Katie. (Org.). The Culture of Inquisition in Medieval England. Cambridge: D. S. Brewer, 2013. p. 8-29. 
KELLY, Henry Ansgar. Questions of Due Process and Conviction in the Trial of Joan of Arc. In: BOLLERMANN, Karen; IZBICKI, Thomas; NERDERMAN, Cary (Ed.). Religion, Power, and Resistance from the Eleventh to the Sixteenth Centuries. Nova York: Macmillian, 2014. p. 81-102.

LOPES, José Reinaldo de Lima. O Direito na História: lições introdutórias. 3. ed. São Paulo: Atlas, 2011a.

LOPES, José Reinaldo de Lima. Uma introdução à história política e social do processo. In: WOLKMER, Antônio Carlos (Org.). Fundamentos de História do Direito. 5. ed. Belo Horizonte: Del Rey, 2011b. p. 351-379.

MIGLIORINO, Francesco. Iniuria e Infamia. Indagine sulla dottrina giuridica medievale. In: BECKER, Cristoph (Org.). Persönlichkeitsrecht und Persönlichkeit des Rechts Gedächtnisschrift für Heinz Hübner (1914-2006). Berlim: LIT-Verlag, 2016. p. 145-177.

MORAIS, Ricardo Manoel de Oliveira. Direito e Verdade em Michel Foucault. Revista Direito e Práxis, v. 5, n. 1, p. 284-314, 2014. https://doi.org/10.12957/dep.2014.9979

NASPOLINI, Samyra. Aspectos históricos, políticos e legais da inquisição. In: WOLKMER, Antônio Carlos. (Org.). Fundamentos de História do Direito. 5. ed. Belo Horizonte: Del Rey, 2006. p. 187-199.

PENNINGTON, Kenneth. Torture and Fear: Enemies of Justice. Rivista Internazionale di Diritto Commune, v. 19, p. 203-242, 2008.

PENNINGTON, Kenneth. The Jurisprudence of Procedure. In: HARTMANN, Wilfried; PENNINGTON, Kenneth. (Org.). The History of Courts and Procedure in Medieval Canon Law. Washington: The Catholic University of America Press, 2016. p. 125-159.

PETERS, Edward. Inquisition. Nova York: Free Press, 1988.

PETERS, Edward. História da tortura. Lisboa: Círculo de Leitores, 1996.

PRODI, Paolo. Uma História da Justiça: do pluralismo dos foros ao dualismo moderno entre consciência e direito. Tradução de Karina Jannini. São Paulo: Martins Fontes, 2005.

RUST, Leandro Duarte. Bulas inquisitoriais: Ad Extirpanda (1252). Revista Diálogos Mediterrânicos, n. 7, p. 200-228, dez. 2014. Disponível em: http://www.dialogosmediterranicos.com.br/index.php/RevistaDM/article/view/124/145. Acesso em: 18 ago. 2020.

THÉRY, Julien. Fama: I'opinion publique comme preuve judiciaire - Aperçu sur la révolution médiévale de l'inquisitoire (XII - XIV siècle). In: LEMESLE, Bruno. La preuve en justice: de I'Antiquité à nos jours. Rennes: PUR, 2003. p. 119-147.

ULLMANN, Walter. Reflections on Medieval Torture. In: ULLMANN, Walter; GARNETT, George (Org.). Law and Jurisdiction in the Middle Ages. Farnhan: Ashgate, 2009. p. 123137. 